\title{
Ecology of Avian Influenza Virus in Wild Birds in Tropical Africa
}

Author(s): Nicolas Gaidet

Source: Avian Diseases, 60(1s):296-301.

Published By: American Association of Avian Pathologists

DOI: http://dx.doi.org/10.1637/11149-051115-Review

URL: http://www.bioone.org/doi/full/10.1637/11149-051115-Review

BioOne (www.bioone.org) is a nonprofit, online aggregation of core research in the biological, ecological, and environmental sciences. BioOne provides a sustainable online platform for over 170 journals and books published by nonprofit societies, associations, museums, institutions, and presses.

Your use of this PDF, the BioOne Web site, and all posted and associated content indicates your acceptance of BioOne's Terms of Use, available at www.bioone.org/page/terms_of_use.

Usage of BioOne content is strictly limited to personal, educational, and non-commercial use. Commercial inquiries or rights and permissions requests should be directed to the individual publisher as copyright holder.

BioOne sees sustainable scholarly publishing as an inherently collaborative enterprise connecting authors, nonprofit publishers, academic institutions, research libraries, and research funders in the common goal of maximizing access to critical research. 


\title{
Review Article-
}

\section{Ecology of Avian Influenza Virus in Wild Birds in Tropical Africa}

\author{
Nicolas Gaidet ${ }^{\mathrm{A}}$ \\ Centre de coopération internationale en recherche agronomique pour le développement (CIRAD), Unité propre de recherche (UPR) Animal et gestion \\ intégrée des risques (AGIRS), Campus International de Baillarguet, 34398 Montpellier, France \\ Received 12 May 2015; Accepted 17 August 2015; Published ahead of print 26 October 2015
}

\begin{abstract}
SUMMARY. Several ecologic factors have been proposed to describe the mechanisms whereby host ecology and the environment influence the transmission of avian influenza viruses (AIVs) in wild birds, including bird's foraging behavior, migratory pattern, seasonal congregation, the rate of recruitment of juvenile birds, and abiotic factors. However, these ecologic factors are derived from studies that have been conducted in temperate or boreal regions of the Northern Hemisphere. These factors cannot be directly translated to tropical regions, where differences in host ecology and seasonality may produce different ecologic interactions between wild birds and AIV. An extensive dataset of AIV detection in wildfowl and shorebirds sampled across tropical Africa was used to analyze how the distinctive ecologic features of Afrotropical regions may influence the dynamics of AIV transmission in wild birds. The strong seasonality of rainfall and surface area of wetlands allows testing of how the seasonality of wildfowl ecology (reproduction phenology and congregation) is related to AIV seasonal dynamics. The diversity of the African wildfowl community provides the opportunity to investigate the respective influence of migratory behavior, foraging behavior, and phylogeny on species variation in infection rate. Large aggregation sites of shorebirds in Africa allow testing for the existence of AIV infection hot spots. We found that the processes whereby host ecology influence AIV transmission in wild birds in the Afrotropical context operate through ecologic factors (seasonal drying of wetlands and extended and nonsynchronized breeding periods) that are different than the one described in temperate regions, hence, resulting in different patterns of AIV infection dynamics.
\end{abstract}

RESUMEN. Estudio recapitulativo- Ecología de los virus de la influenza aviar en aves silvestres en África Tropical.

Se han propuesto varios factores ecológicos para describir los mecanismos por los que la ecología de los hospederos y el ambiente influyen en la transmisión del virus de la influenza aviar (AIV) en las aves silvestres, incluyendo el comportamiento de forrajeo de aves, los patrones migratorios, la congregación de temporada, la tasa de reclutamiento de aves jóvenes, y factores abióticos. Sin embargo, estos factores ecológicos se derivan de los estudios que se han realizado en las regiones templadas o boreales del hemisferio norte. Estos factores no se pueden aplicar directamente a las regiones tropicales, donde las diferencias en la ecología de los hospederos y la estacionalidad pueden producir diferentes interacciones ecológicas entre las aves silvestres y el virus de la influenza aviar. Se utilizó un amplio conjunto de datos de detección del virus de influenza aviar en aves costeras y aves silvestres muestreadas a través de África tropical para analizar cómo las características ecológicas distintivas de las regiones tropicales africanas pueden influir en la dinámica de la transmisión del virus de influenza aviar en las aves silvestres. La fuerte estacionalidad de las lluvias y la superficie de los humedales permiten realizar pruebas de cómo la estacionalidad de la ecología de aves silvestres (fenología de la reproducción y congregación) se relaciona con la dinámica estacional del virus de la influenza aviar. La diversidad de la comunidad de aves silvestres africanas ofrece la oportunidad de investigar la influencia respectiva de los comportamientos migratorios, de los comportamientos de alimentación, y la filogenia sobre la variación de la tasa de infección en las especies. Los grandes sitios de agregación de aves costeras en África permiten las pruebas de la existencia de sitios activos de infección del virus de la influenza aviar. Se encontró que los procesos por los cuales la ecología del hospedero influencia la transmisión del virus de la influenza aviar en aves silvestres en el contexto de África tropical operan a través de factores ecológicos (secado estacional de los humedales y periodos de cría ampliados y no sincronizados) que son diferentes a la que se describen en las regiones templadas, por lo tanto, esto resulta en diferentes patrones en la dinámica de la infección del virus de la influenza aviar.

Key words: host ecology, Africa, tropics, receptivity, hot spot, migration, shorebirds, seasonality, wildfowl, bird, phylogeny

Abbreviation: AIV = avian influenza virus

Knowledge on the relation between host and virus ecology is essential for understanding the dynamics of virus transmission. Several ecologic factors have been associated with the processes whereby host ecology and the environment influence the transmission of avian influenza viruses (AIV) in wild birds, including bird's foraging behavior, migratory behavior, social aggregation, rate of recruitment of juveniles in the host population, water temperature, solar radiation intensity, and desiccation rate $(9,17,18,21)$.

A vast number of empirical studies have been conducted on AIV detection in wild birds, especially during the last decade. Long-term surveillance studies have revealed some consistent patterns in the

\footnotetext{
${ }^{\mathrm{A} C}$ Corresponding author. E-mail: nicolas.gaidet-drapier@cirad.fr
}

variations of AIV infection rate across seasons, species, and geographic locations. Major findings include 1) a recurrent peak in infection rate in wildfowl during the northern autumn (September to November), associated with the timing relative to the period when birds aggregate during their southbound migration and coinciding with the period when immunologically juvenile birds experience their first infection $(25,26) ; 2)$ a constantly higher prevalence in wildfowl species that forage by dabbling rather than by diving or grazing, which is associated with a higher exposure to AIV in surface water-feeding ducks $(17,18)$; and 3) a unique but consistent high prevalence in one shorebird species (the ruddy turnstone, Arenaria interpres) during spring migration at one site (Delaware Bay, United States), related to the locally high abundance of this species and a convergence of host 
(physiology, behavior, and immune status) and ecologic (concurrent horseshoe crab-spawning [Limulus polyphemus]) factors $(14,22)$.

These consistent patterns in the variations of AIV infection rate are derived from studies that have been conducted in temperate or boreal regions of the Northern Hemisphere, especially in dabbling ducks of the Anas genus. These findings cannot be directly translated to tropical regions, where differences in host ecology, climate, and seasonality may produce different ecologic interactions between wild birds and AIV. Wild bird hosts and AIV interact through different processes, such as density dependence of interindividual transmission, rate of first infection and the resulting acquired immunity, or exposure to environmental infection. The ecologic factors through which these processes operate (such as social behavior, reproduction phenology, foraging behavior, migratory behavior, and host-pathogen coevolution) may vary according to the composition and the dynamic of the local host community and the abiotic conditions. Specific ecologic factors and their dynamic are expected to produce different patterns of species, spatial, and temporal variations in AIV prevalence in distinct ecologic contexts.

We have collected and tested for AIV infection in an extensive dataset of samples in wild birds across tropical Africa (about 20,000 birds tested in 20 countries), mostly from wildfowl (Anseriformes) and shorebird (Charadriiformes) species, in collaboration with numerous partners $(9,10)$. Biotic and abiotic conditions vary widely across ecosystems and regions of the African continent; hence, patterns of AIV infection are hard to generalize. However, the African waterbird communities and ecosystems have some specificity in terms of species assemblage, behavior, taxonomy, and seasonality that provide the opportunity to explore in a distinct ecologic context some of the ecologic factors commonly associated with the species and seasonal and geographical variations in AIV infection rate in temperate or boreal regions. I review how some of the processes of host-virus ecologic interactions operate in Afrotropical regions and produce specific dynamics of AIV infection across species, seasons, and locations.

Seasonality of wildfowl ecology and AIV seasonal dynamics. In Afrotropical regions, seasons are determined by rainfall variations rather than temperatures that exhibit lower seasonal variation than in temperate regions (9). Most Afrotropical wetlands experience extreme seasonal variations in their surface area: seasonal rainfall and river flooding inundate a vast network of temporary ponds and floodplains that dry out during the dry season through high evaporation and human extraction. This strong seasonality in wetland habitat distribution and availability impacts the temporal dynamics of breeding and aggregation of the wildfowl species.

In almost all species of wildfowl in the world, birds attempt breeding only once a year, during the most favorable period. In temperate and boreal regions of the Northern Hemisphere, the breeding period of wildfowl species is relatively short (the egg-laying periods lasting for 1 to 5 mo according to latitude) and is synchronized between species (coinciding with the northern spring) (7). In Afrotropical regions, water is the limiting factor for the breeding of wildfowl. The phenology of breeding of Afrotropical wildfowl species is poorly known for most species in most regions. In a recent study, we explored the breeding records (nest and duckling reports) collected across Zimbabwe over a century (from 1910 to 2011) to describe the seasonal patterns of breeding for the most common wildfowl species (J. Mundava, unpubl. data). This study indicates that the breeding season is more extended in African wildfowl species than in temperate or boreal species: the egg-laying period recorded in Zimbabwe stretches over 7 to 12 mo according to species. The peak of the egg-laying period is also asynchronous between species: some species breed mainly in the wet season, while others breed mainly in the dry season. As a result of these extended and asynchronous breeding periods, some young birds are produced year-round within the African wildfowl community. The continuous presence of immunologically naïve young hosts may facilitate the perpetuation of AIV throughout the year.

Seasonal distribution of wildfowl is related to the distribution and availability of wetlands. We monitored the movements of comb ducks (Sarkidiornis melanotos) through satellite telemetry in the Inner Niger Delta, Mali. The surface area of this vast seasonally flooded plain (about $40,000 \mathrm{~km}^{2}$, the second-largest continental wetland of Africa) is up to 20 times higher during the rainy season (flooding period) than at the end of the dry season when only a few permanent wetlands remained. We estimated the spatial distribution of comb ducks by using satellite locations and high spatial and temporal remotely sensed environmental indicators (the normalized difference vegetation index and the modified normalized difference water index measured from Moderate Resolution Imaging Spectroradiometer satellite images) (2). Comb ducks show a strong seasonal variation in their distribution. They use a progressively smaller area, as wetlands dry out during the dry season, and they converge to the few permanent lakes at the end of the dry season. Comb ducks disperse from the Inner Niger Delta after the first heavy rains and will likely breed in temporary ponds and lagoons in the surrounding areas that are formed with rainfall and river flooding. These individual duck movements indicate that a seasonal aggregation of wildfowl occurs in this Afrotropical wetland analogous to temperate regions. However, the process of congregation is more progressive than in temperate regions, as it results from the progressive drying out of wetlands, while in temperate regions, it results from a flocking behavior at premigratory and stopover sites. Boreal and temperate breeding wildfowl also gather during winter at their wintering site but at a time when most birds are likely to have already acquired immunity from previous infections during autumn.

In our large-scale surveillance study, we detected AIV infection in wildfowl in both wet and dry seasons in various countries of western, eastern, and southern Africa. Seasonal variation in AIV prevalence in wildfowl was low and poorly related to the site-specific timing of the end of the dry season when wildfowl aggregate to permanent wetlands (9). Two longitudinal studies of AIV infection in wildfowl, conducted concurrently in Mali (3) and Zimbabwe (4) during 2 yr, detected AIV infection during almost all periods of the year at a low prevalence. The results from these different studies suggest a low but year-round perpetuation of AIV in Afrotropical ecosystems, with a relatively low seasonal variation. This finding contrasts with the high seasonality of AIV circulation measured in wildfowl in temperate regions. In Europe and North America, the proportion of birds infected with AIV reaches locally up to $50 \%-60 \%$ during the northern autumn, with generally no birds found infected in winter or spring $(18,23)$.

In Afrotropical regions, extended and asynchronous breeding seasons produce a continual recruitment of juvenile birds into the host community, instead of the seasonal pulse of juveniles in temperate regions, resulting from the seasonally synchronized breeding periods. Similarly, the seasonal congregation of wildfowl being progressive during the dry season, the rate at which juvenile birds experience their first infection in tropical Africa is likely to be more gradual than in temperate regions. The lower and seasonally less variable but continuous AIV prevalence in Afrotropical regions may result from a slower turnover of susceptible birds in the wildfowl community compared with temperate regions, due to a more continuous recruitment of juvenile birds and a more gradual pace of first infection (Table 1).

AIV perpetuation in migratory shorebirds wintering in Africa. We investigated the circulation of AIV at various sites in Africa that 
Table 1. Differences in the seasonality of wildfowl ecology between temperate and Afrotropical regions and hypothesized influence on AIV transmission dynamics.

\begin{tabular}{|c|c|c|c|c|c|c|}
\hline & Breeding period & $\begin{array}{c}\text { Production of } \\
\text { immunologically } \\
\text { naive juvenile birds }\end{array}$ & $\begin{array}{c}\text { Seasonal } \\
\text { congregation }\end{array}$ & $\begin{array}{l}\text { Rate of first } \\
\text { infection }\end{array}$ & $\begin{array}{l}\text { Turnover of susceptible } \\
\text { birds }\end{array}$ & $\begin{array}{c}\text { Seasonal variation in } \\
\text { AIV prevalence }\end{array}$ \\
\hline $\begin{array}{l}\text { Temperate } \\
\text { regions }\end{array}$ & $\begin{array}{l}\text { Short and synchronized } \\
\text { between species }\end{array}$ & $\begin{array}{l}\text { Brief seasonal } \\
\text { pulse }\end{array}$ & $\begin{array}{l}\text { Flocking } \\
\text { behavior during } \\
\text { migration }\end{array}$ & $\begin{array}{l}\text { Rapid and } \\
\text { synchronized }\end{array}$ & Rapid and seasonal & $\begin{array}{l}\text { High seasonality, } \\
\text { peak in autumn, } \\
\text { basal or no } \\
\text { circulation in } \\
\text { winter and spring }\end{array}$ \\
\hline $\begin{array}{l}\text { Tropical } \\
\text { regions }\end{array}$ & $\begin{array}{l}\text { Extended and } \\
\text { nonsynchronized } \\
\text { between species }\end{array}$ & $\begin{array}{l}\text { Year-round } \\
\text { recruitment }\end{array}$ & $\begin{array}{l}\text { Progressive } \\
\text { aggregation } \\
\text { through drying } \\
\text { of wetlands }\end{array}$ & $\begin{array}{l}\text { Gradual and } \\
\text { year-round }\end{array}$ & Slow and continuous & $\begin{array}{l}\text { Lower and } \\
\text { seasonally less } \\
\text { variable but } \\
\text { continuous } \\
\text { circulation }\end{array}$ \\
\hline
\end{tabular}

constitutes large seasonal aggregation sites of shorebirds, such as Delaware Bay in the United States. In particular, we monitored AIV infection and the presence of AIV-specific antibodies, in various species of migratory shorebirds wintering at the Banc d'Arguin National Park in Mauritania, Africa. The Banc d'Arguin harbor is one of the largest wintering populations of shorebirds in the world (about 2.3 million birds), including the greatest number of ruddy turnstones (up to 10,000 birds) across the Old World (5). The Banc d'Arguin offers vast intertidal flats, where shorebirds aggregate for foraging at their highest density along the East Atlantic Flyway, thanks to an upwelling of cold water rich in nutrients (27).

Birds were sampled at the Banc d'Arguin during four wintering years (2006-2010) at the beginning (mid-November to mid-December) or at the end of the wintering period (late February to mid-April) (10). AIV infection was detected in only one of the ruddy turnstones tested $(n=158)$. This is in contrast with the results from Delaware Bay, where this particular species is consistently found infected at a relatively high prevalence $(>10 \%)$ during spring migration $(11,14,22)$. We detected AIV in other shorebird species at the Banc d'Arguin during the wintering period in every year, although at a consistently low prevalence $(<2 \%)$. No difference in infection rate was found between the beginning (November to December: 0.9\%, 95\% confidence interval $\left.[\mathrm{CI}]: 0.4-1.6 ; \chi^{2}=0.21, P>0.5\right)$ and the end (February to April: $0.7 \%$, 95\% CI: $0.4-1.4$ ) of the wintering period. In addition, one dunlin (Calidris alpina) seroconverted between two consecutive sampling occasions (November 2009 and March 2010). Its infection with AIV likely occurred at the Banc d'Arguin, because this site constitutes the largest southernmost staging site for this species along its migration flyway (5). These results suggest that there is a continuous circulation of AIV in these shorebirds at the Banc d' Arguin during the wintering season. The persistence of AIV in the environment at this coastal tropical site is unlikely due to harsh abiotic conditions, such as high temperatures, solar radiations and wind exposure, salinity, little precipitation, and tidal washing of the tidal flats. In addition, wildfowl (the leading maintenance hosts of AIV (18) are largely absent at this site. The low but regular detection of AIVs in the shorebird community at the Banc d'Arguin suggests that migratory shorebirds should be able to perpetuate AIV throughout their wintering period in Africa.

A consistently low AIV infection rate was also found at other major seasonal aggregation sites of shorebirds that we investigated, including the Sivash (Crimean Peninsula, Ukraine), the Nile River Delta (Egypt, Africa), the Senegal River Delta (Senegal-Mauritania, Africa), the Inner Niger Delta (Mali, Africa), and the Kafue Flats (Zambia, Africa) (10). Despite a large taxonomic and geographic sample coverage (i.e., 69 shorebird species sampled in 25 countries of Africa and western Eurasia), including species $(n=18)$ that had never been tested for AIV infection before, our large-scale surveillance study did not detect any hot spots of AIV infection in shorebirds analogous to the one reported in Delaware Bay during spring migration (10). Therefore, a large aggregation of shorebirds appears to be an insufficient condition for the existence of a hot spot of AIV infection.

Species variation in AIV infection rate within the African wildfowl community. Among species traits, foraging by dabbling has been identified as a major risk factor of AIV infection among wildfowl species $(17,18)$. Dabbling ducks that forage predominantly by filtration with the bill submerged in shallow water, or in surface water by upending, are likely to be more exposed to AIV and to fecal-oral transmission (12). Another species trait that has been poorly investigated to explain differences in AIV infection rate between cohabiting wild bird species concerns the intrinsic difference in host receptivity to AIV (i.e., their permissiveness for infection) (17). This difference in receptivity might be accounted for by species-specific differences in the type of AIV receptors present on their epithelial tissues (16). This receptivity may results from a coevolutionary process between host species and AIV through reciprocal and adaptive genetic changes (24). Species that are phylogenetically closely related likely show a similar receptivity for AIV infection because coevolution between host and pathogens may facilitate the infection in host species that have a shared evolutionary history $(15,20,23)$.

In temperate regions of the Northern Hemisphere, duck species that forage mostly by dabbling almost all belong to the same Anas genus. In contrast, African duck species foraging mainly by dabbling are represented by both Anas species (e.g., Anas erythrorhyncha, Anas undulata, and Anas capensis) and non-Anas species (e.g., Dendrocygna viduata, Dendrocygna bicolor, and Nettapus auritus). The Eurasian migratory wildfowl wintering in sub-Saharan Africa are mainly represented by Anas species of dabbling ducks, in particular, the garganey (Anas querquedula) and the northern pintail (Anas acuta) that hold the largest wintering populations (about 1.5 million and 0.5 million birds, respectively) (6). The wildfowl community found in Afrotropical wetlands hence consists of a diverse assemblage of species, including both Eurasian and African dabbling ducks of the Anas genus, African dabbling duck of non-Anas genus, and African nondabbling ducks (diving or grazing species; Table 2). This diversity of species in the wildfowl community provides the opportunity to tease apart the respective influence of taxonomy (Anas vs. non-Anas), foraging behavior (dabbling vs. nondabbling), and migratory behavior (Eurasian vs. African birds) on species prevalence. 
Table 2. Species composition of the wildfowl community in sub-Saharan Africa (excluding Madagascar) according to their main foraging behavior and their breeding ground (Eurasian or African). ${ }^{\mathrm{A}}$

\begin{tabular}{lll}
\hline Main foraging behavior & Eurasian breeding species & \multicolumn{1}{c}{ African breeding species } \\
\hline Dabbling Anas species & Garganey (Anas querquedula) & Red-billed teal (Anas erythrorhyncha) \\
& Northern pintail (Anas acuta) & Cape teal (Anas capensis) \\
& Northern shoveler (Anas clypeata) & Hottentot teal (Anas hottentota) \\
& Common teal (Anas crecca) & Yellow-billed duck (Anas undulata) \\
& & African black duck (Anas sparsa) \\
Dabbling non-Anas species & & Cape shoveler (Anas smithii) \\
& & White-faced whistling duck (Dendrocygna viduata) \\
& & Fulvous whistling duck (Dendrocygna bicor) \\
& & African pygmy goose (Nettapus auritus) \\
Diving & & Hartlaub's duck (Pteronetta hartlaubi) \\
& Ferruginous ducks (Aythya nyroca) & Cape shelduck (Tadorna cana) \\
Grazing & Common Pochard (Aythya ferina) & Southern pochard (Netta erythrophthalma) \\
& Tufted duck (Aythya fuligula) & White-backed duck (Thalassornis leuconotus) \\
& & Maccoa duck (Oxyura maccoa) \\
& & Comb duck (Sarkidiornis melanotos) \\
& & Egyptian goose (Alopochen aegyptiacus) \\
& & Spur-winged goose (Plectropterus gambensis) \\
\hline
\end{tabular}

\footnotetext{
${ }^{\mathrm{A}}$ The most abundant species (>500,000 birds) in each group are presented in bold (6).
}

We analyzed species variations in AIV prevalence in more than 8,000 wildfowl sampled across Africa (9). In this analysis, taxonomy was a better explanatory variable than foraging or migratory behavior of species. We found a higher prevalence in Anas species than in nonAnas species, even when we account for differences in their foraging behavior (mainly dabbling or not) or their geographical origin (Eurasian or Afrotropical). We found no significant difference in prevalence between Eurasian and African species among ducks of the Anas genus. These results support the hypothesis that there might be intrinsic differences in receptivity to AIV infection between wild bird species, including between wildfowl taxonomic groups.

Habitat and latitudinal differences in exposure to AIV among wintering populations of migratory shorebirds. Shorebirds that winter along the coast of Africa in coastal saline environments breed predominantly in the high Arctic tundra (e.g., red knot, Calidris canutus and sanderling, Calidris alba), whereas species that winter in inlandfreshwater wetlands of sub-Saharan Africa breed at lower latitude (sub-Arctic to boreal regions; e.g., ruff, Philomachus pugnax and wood sandpiper, Tringa glareola) (19). High Arctic-breeding and coastal-wintering species are expected to experience a lower exposure to AIV because they remain year-round in AIV-poor environments. On their breeding ground, these species forage mainly on terrestrial invertebrates in a moist or dry habitat, and on their wintering ground, the environmental persistence of AIV is reduced by salinity, and the dabbling ducks of the Anas genus (i.e., the leading AIV maintenance hosts) are largely absent in both their breeding and wintering habitats (Table 3). Conversely, sub-Arctic boreal-breeding and inland-wintering species are expected to experience a higher exposure to AIV because they use habitats that have a higher potential for AIV transmission (freshwater habitat and cohabitation with dabbling ducks of the Anas genus) throughout their annual cycle.

We investigated the variation in exposure to AIV between shorebird species in relation to differences in environmental conditions of their breeding and wintering grounds, as well as their phylogenetic relatedness (10). Shorebird species were tested for the presence of antibodies specific to AIV because the detection rate of AIV in these birds had been previously found to be low and with little variability between species. AIV-specific antibodies acquired after a natural infection generally persist for about a year in wild ducks and geese $(8,13)$. Analyzing species variation in seroprevalence allows comparing differences in AIV exposure throughout the annual cycle of species. We restricted our analysis to migratory species of shorebirds that cohabit at their wintering site in sub-Saharan Africa. Serum samples were tested for about 900 birds in two distinct habitats: a coastal saline site (the Banc d'Arguin, Mauritania) and an inland freshwater site (the Inner Niger Delta, Mali).

The results show that seroprevalence was highly variable between species $(0 \%$ to $77 \%)$ (10). Contrary to our predictions, no AIV antibody was detected in any of the sub-Arctic boreal-breeding and inland-wintering shorebird species sampled at the freshwater site (the Inner Niger Delta). Among the high Arctic-breeding species sampled concurrently at the coastal site (the Banc d'Arguin), two species had a high seroprevalence (red knot: 77.5\%, 95\% CI: 70.2-83.4; ruddy turnstone: $47.1 \%, 95 \% \mathrm{CI}: 36.8-57.5)$ and two species had a low seroprevalence (sanderling: 4.8, 95\% CI: 0.2-22.7; dunlin: 1.4, 95\% CI: 0.6-3.3). These results do not support our predictions

Table 3. Habitat and latitudinal differences in potential AIV exposure between migratory shorebird species wintering in Africa.

\begin{tabular}{|c|c|c|}
\hline \multicolumn{3}{|c|}{ Risk factors of AIV exposure } \\
\hline Breeding ground & $\begin{array}{l}\text { High Arctic region } \\
\text { Forage mainly on terrestrial invertebrates in moist or } \\
\text { dry habitat } \\
\text { Dabbling ducks of the Anas genus are absent }\end{array}$ & $\begin{array}{l}\text { Sub-Arctic boreal region } \\
\text { Forage mainly in freshwater aquatic habitat } \\
\text { Cohabit with dabbling ducks of the Anas genus }\end{array}$ \\
\hline Wintering ground & $\begin{array}{l}\text { Coastal region } \\
\text { Forage in saline habitat, where virus survival is lower } \\
\text { Dabbling ducks of the Anas genus are absent }\end{array}$ & $\begin{array}{l}\text { Inland region } \\
\text { Forage in freshwater habitat where virus survival is higher } \\
\text { Cohabit with dabbling ducks of the Anas genus }\end{array}$ \\
\hline
\end{tabular}


about latitudinal and habitat differences in AIV exposure among shorebird species. However, a very similar pattern in species variation in AIV seroprevalence, according to the mean latitude of the breeding range, can be observed among the species of shorebirds that had been tested for serology at Delaware Bay $(1,10,22)$.

The high difference in seroprevalence measured at both Banc d'Arguin and Delaware Bay between these phylogenetically related sandpiper species, which share many ecologically traits and that forage side by side at their wintering and migratory stopover sites, is puzzling. It may result from an intrinsic difference between species in the receptivity to AIV infection or in their ability to mount and maintain an acquired antibody-mediated immune response or both. The high antibody prevalence (about 50\%-90\%) but low infection rate (about 1\%) found in the red knot at both Banc d'Arguin (10) and Delaware Bay $(1,22)$, as well as in the ruddy turnstone at Banc d'Arguin, indicate that these birds experience a prior high AIV infection rate at some other sites during their annual cycle. This suggests the existence of potential hot spots of AIV infection for these species along their migration journey that have yet to be discovered.

Conclusions. Our surveillance studies of AIV in different waterbird communities and different wetland ecosystems in Africa indicate that the processes whereby host ecology influence AIV transmission in wild birds operate through different host ecologic factors in the Afrotropical regions, hence resulting in different patterns of seasonal and species variations of AIV infection rate in wild birds. AIVs and their natural wild bird hosts are present worldwide in a variety of ecosystems, and low pathogenic or highly pathogenic strains of AIV represent a recurrent sanitary problem on all continents. However, the ecologic drivers of host-virus interactions vary in their nature and their relative influence between different geographical and ecologic contexts. Therefore, the pattern of AIV variations between species, seasons, and geographic locations is not global. There are still many unknowns about AIV-host interactions. AIV surveillance in different ecologic context provides new insights for a better understanding of AIV ecology in wild birds.

\section{REFERENCES}

1. Brown, D. J., M. P. Luttrell, R. D. Berghaus, W. Kistler, S. P. Keeler, A. Howey, B. Wilcox, J. Hall, L. Niles, A. Dey, G. Knutsen, K. Fritz, and D. E. Stallknecht. Prevalence of antibodies to type A influenza virus in wild avian species using two serologic assays. J. Wildl. Dis. 46:896-911. 2010.

2. Cappelle, J., N. Gaidet, S. A. Iverson, J. Y. Takekawa, S. H. Newman, B. Fofana, and M. Gilbert. Characterizing the interface between wild ducks and poultry to evaluate the potential of transmission of avian pathogens. Int. J. Health. Geogr. 10:60. 2011.

3. Cappelle, J., R. Servan de Almeida, B. Fofana, M. Dakouo, G. Balanca, P. Gil, E. Albina, and N. Gaidet. Circulation of avian influenza viruses in wild birds in Inner Niger Delta, Mali. Influenza Other Respir. Viruses 6: 240-244. 2012

4. Caron, A., C. Abolnik, J. Mundava, N. Gaidet, C. E. Burger, B. Mochotlhoane, L. Bruinzeel, N. Chiweshe, M. de Garine-Wichatitsky, and G. S. Cumming. Persistence of low pathogenic avian influenza virus in waterfowl in a Southern African ecosystem. EcoHealth 8:109-115. 2011.

5. Delany, S., D. Scott, T. Dodman, and D. Stroud. An atlas of wader populations in Africa and Western Eurasia. Wetlands International, Wageningen, the Netherlands. 2009.

6. Delany, S., and S. Scott. Waterbird population estimates, 3rd ed. Wetlands International Global Series, No. 12. Wetlands International, Wageningen, the Netherlands. 2002.

7. del Hoyo, J., A., Elliot, and J. Sargatal. Handbook of the birds of the world. Volume 1: Ostrich to ducks. Lynx Edicions, Barcelona, Spain. 1992.

8. Fereidouni, S. R., C. Grund, R. Hauslaigner, E. Lange, H. Wilking, T. C. Harder, M. Beer, and E. Starick. Dynamics of specific antibody responses induced in mallards after infection by or immunization with low pathogenicity avian influenza viruses. Avian Dis. 54:79-85. 2010.

9. Gaidet, N., A. Caron, J. Cappelle, G. S. Cumming, G. Balança, S. Hammoumi, G. Cattoli, C. Abolnik, R. Servan de Almeida, P. Gil, S. R. Fereidouni, V. Grosbois, A. Tran, J. Mundava, B. Fofana, A. B. Ould El Mamy, M. Ndlovu, J. Y. Mondain-Monval, P. Triplet, W. Hagemeijer, W. B. Karesh, S. H. Newman, and T. Dodman. Understanding the ecological drivers of avian influenza virus infection in wildfowl: a continental-scale study across Africa. Proc. R. Soc. B 279:1131-1141. 2012.

10. Gaidet, N., A. B. Ould El Mamy, J. Cappelle, A. Caron, G. S. Cumming, V. Grosbois, P. Gil, S. Hammoumi, R. S. de Almeida, S. R. Fereidouni, G. Cattoli, C. Abolnik, J. Mundava, B. Fofana, M. Ndlovu, Y. Diawara, R. Hurtado, S. H. Newman, T. Dodman, and G. Balança. Investigating avian influenza infection hotspots in Old-World shorebirds. PLoS ONE 7(9):e46049. 2012. doi: 10.1371/journal.pone.0046049

11. Hanson, B. A., M. P. Luttrell, V. H. Goekjian, L. Niles, D. E. Swayne, D. A. Senne, and D. E. Stallknecht. Is the occurrence of avian influenza virus in Charadriiformes species and location dependent? J. Wildl. Dis. 44:351-361. 2008.

12. Hill, N. J., J. Y. Takekawa, C. J. Cardona, J. T. Ackerman, A. K. Schultz, K. A. Spragens, and W. M. Boyce. Waterfowl ecology and avian influenza in California: do host traits inform us about viral occurrence? Avian Dis. 54:426-432. 2010.

13. Hoye, B. J., V. J. Munster, H. Nishiura, R. A. M. Fouchier, J. Madsen, and M. Klaassen. Reconstructing an annual cycle of interaction: natural infection and antibody dynamics to avian influenza along a migratory flyway. Oikos 120:748-755. 2010.

14. Krauss, S., D. E. Stallknecht, N. J. Negovetich, L. J. Niles, R. J. Webby, and R. G. Webster. Coincident ruddy turnstone migration and horseshoe crab spawning creates an ecological 'hot spot' for influenza viruses. Proc. R. Soc. B 277:3373-3379. 2010.

15. Longdon, B., J. D. Hadfield, C. L. Webster, D. J. Obbard, and F. M. Jiggins. Host phylogeny determines viral persistence and replication in novel hosts. PLoS Pathog. 7(9): e1002260. 2011. doi: 10.1371/journal.ppat. 1002260

16. Matrosovich, M., J. Stech, and H. D. Klenk. Influenza receptors, polymerase and host range. Rev. Sci. Tech. 28:203-217. 2009.

17. Munster, V. J., and R. A. M. Fouchier. Avian influenza virus: of virus and bird ecology. Vaccine 27:6340-6344. 2009.

18. Olsen, B., V. J. Munster, A. Wallensten, J. Waldenstrom, A. D. M. E. Osterhaus, and R. A. M. Fouchier. Global patterns of influenza a virus in wild birds. Science 312:384-388. 2006.

19. Piersma, T. Using the power of comparison to explain habitat use and migration strategies of shorebirds worldwide. J. Ornithol. 148(Suppl. 1): 45-59. 2007.

20. Roche, B., S. Morand, E. Elguero, T. Balenghien, J. F. Guégan, and N. Gaidet. Does host receptivity or host exposure drives dynamics of infectious diseases? The case of West Nile Virus in wild birds. Infect. Genet. Evol. 33:11-19. 2015.

21. Stallknecht, D. E., V. H. Goekjian, B. R. Wilcox, R. L. Poulson, and J. D. Brown. Avian influenza virus in aquatic habitats: what do we need to learn? Avian Dis. 54:461-465. 2010.

22. Stallknecht, D. E., M. P. Luttrell, R. Poulson, V. Goekjian, L. Niles, A. Dey, S. Krauss, and R. G. Webster. Detection of avian influenza viruses from shorebirds: evaluation of surveillance and testing approaches. J. Wildl. Dis. 48:382-393. 2012

23. Streicker, D. G., A. S. Turmelle, M. J. Vonhof, I. V. Kuzmin, G. F. McCracken, and C. E. Rupprecht. Host phylogeny constrains crossspecies emergence and establishment of rabies virus in bats. Science 329: 676-9. 2010

24. van Dijk, J. G. B., R. A. M. Fouchier, M. Klaassen, and K. D. Matson. Minor differences in body condition and immune status between avian influenza virus-infected and noninfected mallards: a sign of coevolution? Ecol. Evol. 5:436-449. 2015.

25. van Dijk, J. G. B., B. J. Hoye, J. H. Verhagen, B. A. Nolet, R. A. M. Fouchier, and M. Klaassen. Juveniles and migrants as drivers for seasonal epizootics of avian influenza virus. J. Anim. Ecol. 83:266-275. 2014.

26. Webster, R. G., W. J. Bean, O. T. Gorman, T. M. Chambers, and Y. Kawaoka. Evolution and ecology of influenza A viruses. Microbiol. Rev. 56:152-179. 1992 
27. Zwarts, L., A. M. Blomert, B. J. Ens, R. Hupkes, and T. M. van Spanje. Why do waders reach high feeding densities on the intertidal flats of the Banc d'Arguin, Mauritania? Ardea 78:39-52. 1990.

\section{ACKNOWLEDGMENTS}

These field studies were conducted under four international programs funded by various agencies: the Gripavi project sponsored by grants from the French Ministry of Foreign Affairs, the Technical Cooperation Programme (TCP) of the Food and Agriculture Organization of the United Nations (FAO) through additional grants from the government of France, the United States Agency for International Development (USAID)-sponsored Global Avian Influenza Network for Surveillance (GAINS) project, and the European Union-funded New Flubird Project. I am grateful to all the numerous ornithologists and veterinarians who participated in field operations and to the various laboratory teams who processed the samples. I thank J. Cappelle, A. Caron, and G. Balança Centre de coopération internationale en recherche agronomique pour le développement (CIRAD) who collaborated with most of these studies, as well as G. Cumming (Percy FitzPatrick Institute of African Ornithology) for sharing data from southern Africa. 